УДК 336.2:339.5

DOI 10.15826/itr.2017.3.3.038

\title{
CUSTOMS MEDIATION IN FOREIGN TRADE: SCIENTIFIC AND PRACTICAL ASPECTS
}

\author{
Evgeny P. Bondarenko \\ Ternopil National Economic University, Ternopil, Ukraine \\ ORCID 0000-0002-4783-6919 \\ Fedor P. Tkachyk \\ Ternopil National Economic University, Ternopil, Ukraine \\ ORCID 0000-0002-4783-6919
}

\begin{abstract}
The activity of customs clearance agents in the procedure of customs clearance of goods has a substantial importance. Their professional knowledge helps the subjects of foreign economic activity to accomplish the appropriate customs procedures in proper time, and therefore to accelerate the foreign trade turnover of goods.

As a problem statement it is expedient to study scientific, theoretical and pragmatic peculiarities of customs clearance agents functioning in the sphere of foreign trade. It would take into account European priorities and the current state of the Ukraine's economy development.

This article is intended to systematize and structure theoretical developments and practical peculiarities in the sphere of effective customs mediation organization in the context of foreign trade intensification and establishment of productive relations with international partners of Ukraine.

This article defines the relationship of the basic concepts of the state customs business in the context of elements' identification of customs mediation. The essence of customs mediation in foreign economic activity and principles of international intermediaries' activity are described. The advantages and problematic aspects of customs clearance agents attraction are outlined. The main indicators of Ukraine's foreign trade are analyzed. Much attention is given to the adjustment of relations between Ukraine, the EU countries and Asia as these cooperation vectors are characterized by high dynamism in export and import of goods. In accordance with the investigation of foreign experience in the sphere of customs mediation, and in the context of intensification of foreign trade activity, the ways of increasing the effectiveness of intermediary services on customs clearance and declaration by national enterprises have been formed
\end{abstract}

\section{KEYWORDS}

Goods declaration, foreign trade, customs, customs clearance, customs mediation, customs broker, fiscal policy

\section{HIGHLIGHTS}

1. The use of customs broker services in Ukraine is a necessary step towards the further integration of the country into the civilized development of its external economic relations

2. The professional brokers and the state are interested in developing a unified regulatory and legal framework, that would contribute to creating the favourable climate in the market of customs services

3. The adaptation of foreign experience of regulating the activities of the customs brokers can improve the relations between customs broker, the participants of foreign economic activity and customs divisions of Ukraine 


\title{
ТАМОЖЕННОЕ ПОСРЕАНИЧЕСТВО ВО ВНЕШНЕЙ ТОРГОВАЕ: НАУЧНО-ПРАКТИЧЕСКИЕ АСПЕКТЫ
}

\author{
Е. П. Бондаренко \\ Тернопольский национальный экономический университет, \\ г. Тернополь, Украина \\ ORCID 0000-0002-4783-6919 \\ Ф. П. Ткачик \\ Тернопольский нацииоальный экономический университет, \\ 2. Тернополь, Украина \\ ORCID 0000-0002-4783-6919
}

\begin{abstract}
АННОТАЦИЯ
В процедуре таможенного оформления товаров существенную роль играют таможенные посредники, чей профессиональный опыт и знания помогают субъектам внешнеэкономической деятельности своевременно осуществлять таможенные процедуры, а, следовательно, ускорить внешнеторговый оборот. В связи с этим возникла необходимость изучения теории и практики функционирования таможенных посредников в сфере внешней торговли, а также особенностей их деятельности с учетом европейских приоритетов и современного состояния экономики Украины. Цель статьи заключается в систематизации и структуризации теоретических положений и изучение сложившейся практики организации эффективного таможенного посредничества в контексте активизации внешней торговли и налаживания продуктивных отношений Украины с международными партнерами. В статье выявлена взаимосвязь основных понятий государственного таможенного дела на основе идентификации элементов таможенного посредничества. Определены сущность таможенного посредничества во внешнеэкономической деятельности, принципы деятельности международных посредников. Отмечены преимущества и проблемные аспекты привлечения таможенных посредников. Проанализированы основные показатели внешней торговли Украины, значительное внимание уделено налаживанию отношений Украины со странами ЕС и Азии, поскольку данные векторы сотрудничества характеризуются высоким динамизмом в сфере экспорта и импорта товаров. На основе исследования международного опыта применения таможенного посредничества для активизации внешнеторговой деятельности предложены пути повышения эффективности посреднических услуг по таможенному оформлению и декларированию
\end{abstract}

\section{КЛЮЧЕВЫЕ СЛОВА}

Декларирование товаров, внешняя торговля, таможенное дело, таможенное оформление, таможенное посредничество, таможенный брокер, фискальная политика

\section{ОСНОВНЫЕ ПОЛОЖЕНИЯ}

1. Использование услуг таможенных брокеров в Украине является необходимым шагом на пути дальнейшей интеграции страны в международное экономическое пространство и цивилизованное развитие ее внешнеэкономических связей

2. Профессиональные брокеры и государство заинтересованы в разработке единой нормативно-правовой базы, которая будет способствовать созданию благоприятного климата для развития рынка таможенных услуг

3. Адаптация зарубежного опыта регулирования деятельности таможенных брокеров позволит улучшить отношения между ними и другими участниками внешнеэкономической деятельности и таможенными органами Украины 


\section{Relevance of the research topic}

The restructuring of customs legislation which is in progress in our country for a long time, covers almost all aspects of the customs business including the sphere of intermediary customs services. The customs law institute is constantly in the process of development and improvement. At each stage, there are certain problems and difficulties with the implementation of individual provisions of the legislation on the specified issues into practice which indicates the necessity for further search of new forms, models and mechanisms of customs mediation.

State's influence and interference in the sphere of foreign economic relations under crisis conditions of the national economy is related to the requirement of organization and management of foreign trade processes, the establishment of certain rules and restrictions in order to regulate relations which arise because of the movement of goods and vehicles across the customs border of Ukraine.

Today, Ukraine is interested in creation of the appropriate legal field for customs clearance agents as participants of customs jural relationships. The subjects of customs mediation have their own legal status defined in the norms of customs legislation, but it can be stated that organizational and legal support of the activities of customs clearance agents needs improvement which will promote the development of the customs infrastructure indispensable all around, the qualitative process of passing customs formalities and the intensification of foreign trade activity.

\section{Problem statement}

Under conditions of globalization of world economy, European integration of the national economy and the dynamic development of foreign economic activity the importance of services, provided when goods are transferred through the customs border of Ukraine, increases. The term of passing the customs formalities, the financial expenses of the subjects of importers and exporters, timeliness and completeness of the customs payments administration depend on the quality and completeness of such services. Thus, issues of the development of customs mediation in foreign trade require more fundamental scientific researches.

\section{Analysis of recent researches and publications}

Significant contribution to the research of the relevant peculiarities of the customs regulation accomplishment of foreign economic activity was made by such scholars as I. Berezhniuk, A. Voitseshchuk, T. Voronchenko, O. Hrebelnyk, A. Krysovatyi, A. Mazaraki, V. Mantusov, T. Melnyk, P. Pashko, L. Pismachenko, K. Puhachevska, V. Fedosov and others. It is also worth mentioning that in recent years the attention of scholars is attracted by trends of functioning of customs clearance agents in Ukrainian fiscal practice, which were investigated in the works by I. Bondarenko, A. Dunska, O. Korniichuk, O. Korobkova, Y. Medvid, I. Svitlak and others.

It is important to note that the global aspects of the mediation implementation in the sphere of customs are also the subject of the investigation of foreign experts. In particular, in this direction we can distinguish the following: T. Cantens, W. Czyzowicz, A. Grainger, E. Gwardzinska, G. Llanto, C. Milner, J. Nieva, F. L. Palomares, C. Pastor and others.

The questions of customs regulation became more relevant in the context of globalization and the growth in global trade $[1 ; 2]$. In recent years much research has investigated the simplification of the international business regulations [3] and reduction of trade costs [4]. Some research contains information on the impact of customs regulation to the socio-economic development of the regions [5]. However, the findings of above mentioned works necessarily give a somewhat piecemeal and disjointed view of the role of customs mediation in the global integration processes.

\section{Selection of previously unsettled parts of the general issue}

At the same time, the development of the effective customs mediation plays 
a significant role at the present stage in the context of the intensification of foreign economic relations between Ukraine, the EU countries, Asia and America. At the current stage, the ways of improving the organizational and legal basis for the activities of customs brokers, conditions of their functioning, which would take into account the latest technologies, are not sufficiently worked up. It is also important to substantiate the procedures for monitoring the quality of provided services in the sphere of customs declaration and clearance which would take into account the global experience.

The aim of the article is to extend the scientific researches and to substantiate the practical aspects of customs mediation functioning in the foreign trade.

\section{Presenting main material}

Trends of the conduction of international trade activity affirm its high significance as an external factor of national economic development. International trade actively integrates national market subjects and state institutions into the global economic space. The objects of the international commodity exchange, which are completely absorbed by all spheres of social reproduction and consumption, become, in some cases, the basic resources of scientific and technological progress.

The indicator of the quality and effectiveness of customs services in international trade is the speed of foreign trade agreements' implementation, the speed of goods movement across the customs border of Ukraine, as well as the transparency of the state administration of foreign economic activity.

These criteria are influenced by covenanters of foreign trade agreement and a large number of professional participants of the foreign trade agreement implementation: ship holders, carriers, forwarders, ports, marine agents, chartering brokers, customs brokers and others.

In the sector of customs, such services are provided by specialized companies which, in accordance with the Customs Code of Ukraine, are authorized to carry out such activities. The analysis of the regulatory and legal framework in the sphere of customs shows that it mainly recalculates the customs services but it does not reveal the economic and legal character of customs services. Despite the explicit orientation of the provisions of the Customs Code of Ukraine to international norms, there is no concept of "customs service" in it ${ }^{1}$.

The basic concepts in the customs sphere, which are related to the process of customs control, are defined by the Customs Code of Ukraine. The interconnection of the main concepts mentioned in the Customs Code of Ukraine, shown in Figure 1, demonstrates that the basic concepts in the customs sphere, fixed in the current customs code, are: customs sphere, customs policy, customs control, customs procedures, customs regimes, customs clearance.

The concept of "customs service" in Ukrainian practice is not identified, al-

${ }^{1}$ Customs Code of Ukraine. 2012. Available at: http://zakon4.rada.gov.ua/laws/show/4495-17

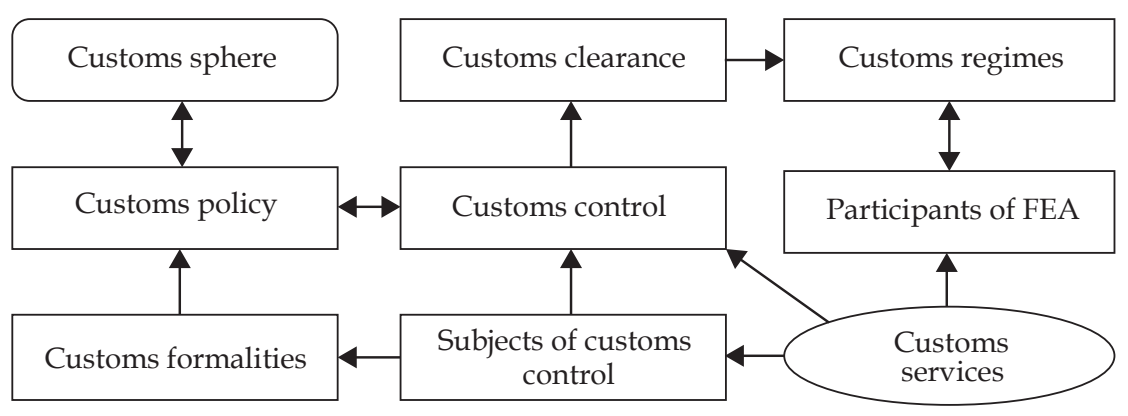

Figure 1. Interconnection of basic concepts of state customs sphere in the context of identification of the elements of customs mediation 
though, at the level of concepts of the State Fiscal Service of Ukraine, this term has been actively used in recent years.

I. Bondarenko defines customs services as legally provided activity of customs authorities, specialized customs establishments and organizations, as well as subjects of entrepreneurial business, which is accomplished on the initiative of individuals and legal entities, aimed at the realization of rights, freedoms and lawful interests in the sphere of customs activities [6, p. 47].

According to A. Dunska, trade and intermediary operations in the foreign economic activity are operations of purchase and sell of goods which are accomplished by the instructions of an exporter or an importer by an independent intermediary firm on the basis of special orders or individual agreements [7, p. 90].

Customs broker - is any person having a valid license certificate or a professional identification card, issued by the competent state regulatory bodies. The profession of customs broker includes the following range of services: consulting on customs law issues, preparation of customs documentation for export and import operations' registration, signing and submission of documents related to customs declaration, representation of interests in the bodies authorized to implement customs policy etc. [8, p. 2].

European practice shows the existence of customs mediation in three forms:

- customs brokers are considered to be the only authorized organizations to implement intermediary activity (Portugal);

- customs brokers accomplish direct representation (Poland, Italy) or indirect representation (Belgium) of the subject of foreign economic activity;

- free choice of people - customs brokers with different types of functioning and customs qualifications (Germany, Great Britain) [9].

Knowledge and experience of customs brokers in the sphere of customs legislation and regulation can be useful not only for subjects of foreign economic activity, but also for state fiscal authorities. Despite the fact that customs brokers help individuals in documenting the customs clearance of goods, they also operate in the interest of the state, since the execution of customs procedures involves the payment of appropriate tax revenues, which replenish the budget resources ${ }^{2}$.

In the legislative area, the main purpose of the fiscal authorities is to create favorable conditions for the development of the foreign economic activity, to ensure the security of society, to protect customs interests of Ukraine, that is, customs activity, the special feature of which is its mandatory character for participants of foreign trade activity ${ }^{3}$.

Customs services are the result of activities of fiscal authorities and enterprises in the customs sphere, the main purpose of which is to facilitate the passing of consignments across the customs border of Ukraine. Depending on the subject, which provides customs services, we can distinguish between the state customs services and customs services of private enterprises. In this case, SFS of Ukraine provides state customs services. Among services of private enterprises, we can mention services, which are provided by customs brokers, owners of customs warehouses, duty-free shops, free economic zones, customs complexes and other enterprises.

The analysis of the norms of customs legislation allowed us to systemize the general list of customs services provided by intermediaries in the customs sphere: consultations on customs legislation and foreign economic activity issues; expert assessment of documentation provided for the declaration of goods and vehicles; determination of the code of goods according to the Ukrainian Classifier of Goods of Foreign Economic Activity; working out the foreign economic contracts on the terms of the customer; de-

2 WCO Study Report on Customs Brokers. World Customs Organization, 2016. Available at: http://www.wcoomd.org/en/topics/facilitation/ /media/WCO/Public/Global/PDF/Topics/Facilitation/Instruments $\% 20$ and $\% 20$ Tools/ Tools/Study\%20Report \%20on \%20Customs \% 20 Brokers/WCO $\% 20$ Study $\% 20$ Report $\% 20$ on $\% 20$ Customs\%20Brokers EN.ashx.

3 Customs Code of Ukraine. 2012. Available at: http://zakon4.rada.gov.ua/laws/show/4495-17. 
claring services (filling in declarations, documents, working out (filling in) specifications, invoices, other accompanying documents); work with goods, which are under customs control in the warehouse of temporary storage or in the customs licensed warehouse (sorting, drying, marking etc.) and the provision of other works and services related to the realization of right to move objects across the customs border of the state.

In many countries, customs clearance of goods and vehicles is usually implemented, as a rule, only with participation of customs brokers. Some especially large importers keep staff professionals who work exclusively for this company. However, in general, customs brokers are employees of private agencies acting on behalf of different importers and are professional intermediaries. In any case, customs broker must have a licensed permission to implement customs mediation.

In Australia, customs brokers are licensed by the Australian Customs Service and some are members of the Customs Brokers and Forwarders Council of Australia. In Canada customs brokers are licensed by the Canada Border Service Agency (Canada Customs) and most are members of the Canadian Society of Customs Brokers. To operate as a customs broker in New Zealand, one needs a Unique User Identification (UUI). UUI Accreditation can be achieved by sitting and passing three exams set by the Customs Brokers and Freight Forwarders Federation of New Zealand Inc. (CBAFF) [10].

Receiving the services from the customs broker, customers, who are subjects of households, receive the following benefits:

- there is an opportunity to receive services of highly skilled specialists in such specific area as customs declaration and customs transportation (since customs brokers are subjects to certain financial, professional, qualification, organizational, technical and special requirements, and this, in its turn, reduces the risk of customers of such intermediaries);

- the expenses for services related to the declaration of goods and vehicles which are moved across the customs bor- der, as well as the transportation of goods which are under customs control with participation of customs intermediaries, in the customs sphere, are considerably less, since they are calculated in the amount of a certain percentage to the volume of goods which are moved (transported);

- a significant increase in the volume of export and import operations and their prompt execution, with the help of the subjects of entrepreneurial activity in the customs sphere, reduces the growth of own expenses for such purposes, as well as a significant time savings take place [11, p. 51].

The owners of warehouses and owners of warehouses for temporary storage are members of the main subjects that provide services for the storage of goods which are under the customs control. The storage of goods under customs control enables the subject of foreign economic activity to accomplish all permitting procedures and complete the process of passing customs formalities without physically moving goods from the warehouse territory.

From January 1, 2015 till June 28, 2015 249 licenses for customs broker activity implementation were issued (in accordance with the Law of Ukraine of March 2, 2015 № 222-VIII “On Licensing of the Household Activity Types", from June 28, 2015 licensing of customs broker activity was terminated and licenses for customs broker activity were declared invalid). From June 28, 2015, permits for implementation of customs broker activity are provided by including enterprises in the customs brokers' register. 4152 permits were granted from June 28, 2015 till December 31, 2015. On January 1, 2016 there were 310 customs warehouses which implemented their activity. The number of enterprises authorized to open and operate the customs warehouse on June 1, 2017 was 291 units, most of them located in Kyiv, Odesa and Dnipropetrovsk custom houses of SFS of Ukraine ${ }^{4}$.

4 Register of companies granted permission to open and operate a bonded warehouse. 2017. Available at: http://sfs.gov.ua/dovidniki-reestri--perelik/reestri/94929.html. 
When analyzing the role of the subjects of intermediary activity in the customs sphere in the process of moving goods, objects, vehicles and for customs activity itself, it is important to draw attention to the problem aspects of regulation and implementation of this activity, which concern both SFS of Ukraine and the intermediary quarters:

- firstly, the absence of transparent legal field for intermediaries' activity in the customs sphere;

- secondly, increase in the number of offences committed by customs clearance agents;

- thirdly, the abuse of customs clearance agents in the market of customs services (overvalued prices for customs services, low quality of services);

- fourth, low level of interaction of customs authorities with customs clearance agents [12, p. 14].

The involvement of the domestic economy in world globalization measures contributes to the expansion of Ukraine's possibilities to conduct trade operations in international markets. Despite the favourable external conditions for the development of foreign trade there exist internal obstacles - the military and political conflict in the east and the south of the country, the deterioration of economic relations with some countries, crisis state of the state's economy, the instability of the foreign exchange policy, frequent changes and additions in the customs and tax administration sphere, corruption phenomena and so on. As a result, conditions and possibilities of co- operation of domestic enterprises with foreign partners change. Some areas of international trade cooperation become prolonged, form regularities of their development, others are short-term, reflecting certain trends of cooperation.

However, hoping for an effective economic growth in Ukraine through excessive opening and regulation of external economic activity sphere, at this stage, is threatening for the national security of the state. This forces us to digress from the conditions of open liberalism, to apply and optimize the tools of customs and tariff regulation more widely. Without full awareness of the current regulatory and fiscal parameters of the customs and tariff regulation, the conduction of optimization and wider implementation of protective measures are extremely complicated [13].

Nevertheless, Ukraine's foreign trade operations with commodities in 2016 were accomplished with partners from 217 countries. Ukraine exported goods to 191 countries, imported from 201 countries. The number of enterprises, engaged in foreign trade of goods, amounted to 14700 units in export and 22300 units in import.

Export of goods in 2016 amounted to 36.4 billion USD and decreased by $4.6 \%$ of the volume of 2015. The import of goods amounted to 39.2 billion USD and increased by $4.6 \%$ respectively. Negative balance of foreign trade of goods amounted to 2.9 billion USD (positive balance was observed in 2015 and amounted to 0.6 billion USD) (Table 1).

It should be noted that the formation of a positive balance in 2015 was influ-

Dynamics of the main indicators of Ukraine's foreign trade in 2011-2016

\begin{tabular}{|c|c|c|c|c|c|}
\hline \multirow[t]{2}{*}{ Years } & \multicolumn{2}{|c|}{ Export } & \multicolumn{2}{|c|}{ Import } & \multirow{2}{*}{$\begin{array}{c}\text { Balance } \\
\begin{array}{c}\text { Amount, } \\
\text { thousand USD }\end{array}\end{array}$} \\
\hline & $\begin{array}{c}\text { Amount, } \\
\text { thousand USD }\end{array}$ & $\begin{array}{l}\text { in } \% \text { for the } \\
\text { previous year }\end{array}$ & $\begin{array}{c}\text { Amount, } \\
\text { thousand USD }\end{array}$ & $\begin{array}{l}\text { in } \% \text { for the } \\
\text { previous year }\end{array}$ & \\
\hline 2011 & 68394195.7 & 133.0 & 82608240.0 & 136.0 & -14214044.3 \\
\hline 2012 & 68809810.6 & 100.6 & 84658059.9 & 102.5 & -15848249.3 \\
\hline 2013 & 63312022.1 & 92.0 & 76963965.4 & 90.9 & -13651943.3 \\
\hline 2014 & 53901689.1 & 86.5 & 54428716.9 & 71.8 & -527027.8 \\
\hline 2015 & 38127149.7 & 70.7 & 37516443.0 & 68.9 & 610706.7 \\
\hline 2016 & 36361711.2 & 95.4 & 39249797.2 & 104.6 & -2888086.0 \\
\hline
\end{tabular}


enced by individual commodity groups: ferrous metals (7.4 billion USD), grain crops (5.9 billion USD), fat and oils of vegetable or animal origin (3.1 billion USD), ores, slag and ashes (1.6 billion USD), seeds and fruits of the oil plants (1.3 billion USD), wood and wooden products (1.0 billion USD). The export coverage ratio in 2015 was 1.02 (in 2013 - 0.82). However, these data are not particularly consolatory taking into account that in 2016 the balance again amounted to -880 686.4 thousand USD.

The analysis of the dynamics of export across continents showed that Ukraine exported mainly to the EU countries and Asia. Nevertheless, despite the decrease of the export indices from 2011 till 2016, it should be noted that the strategic partners for Ukraine in this context were constantly the EU countries (Figure 2) [11].

The dynamics of goods import in 2016 had a growing trend in external relations with the Asian and EU countries and a declining trend in relations with CIS countries (Figure 3$)^{5}$.

${ }^{5}$ State Statistics Service of Ukraine. Available at: https://ukrstat.org/uk/operativ/menu/ menu_u/zed.htm.
Thus, the foreign trade of Ukraine is clearly characterized by the predominance of import operations over export operations. This, primarily, reflects the consumer policy of our state: we are ready to buy everything what us missing, but not to produce ourselves. Accordingly, domestic enterprises do not have a lot to sell in the external market.

Relatively stable and favourable conjuncture for goods of Ukrainian export although provided an increase in external revenues, however, the production capacities of the export leaders' spheres exhausted themselves completely. External trade in Ukraine has become largely one-way communication, that is, negative balance of the trade shows a significant predominance of import over export into our country and its mainly raw material component, rather than finished products, as it is in developed countries.

The absolute condition for the adaptation of the system of state customs regulation is to ensure continuous monitoring of the indicators of the activity efficiency of the customs authorities and the quality of their respective customs procedures during customs control and registration.

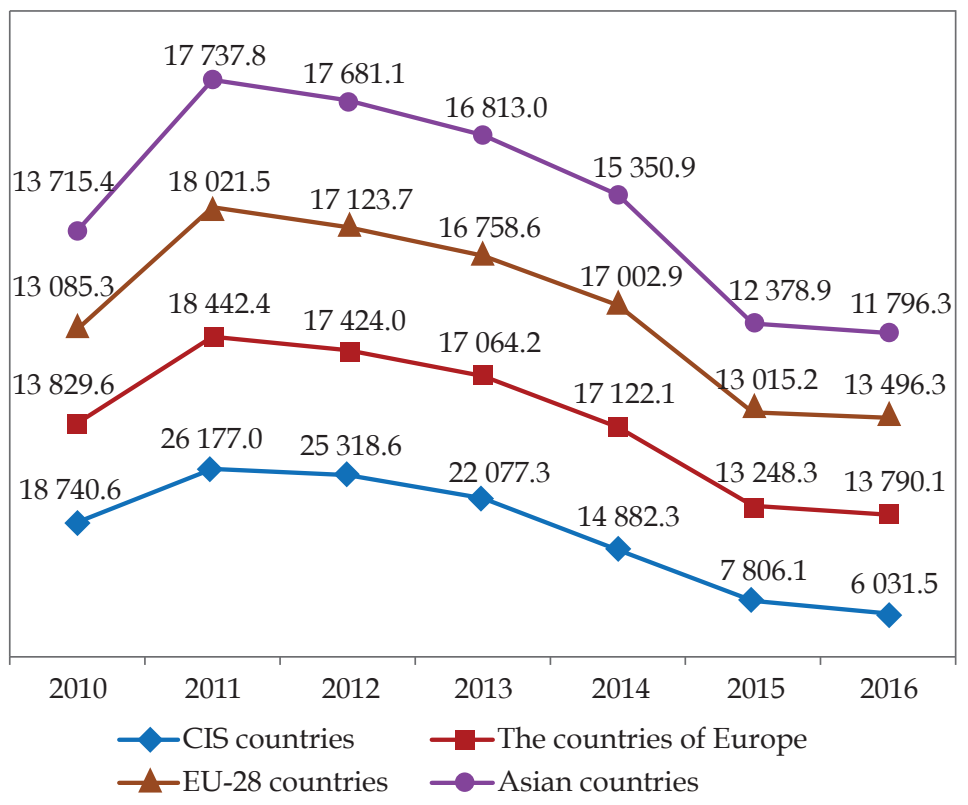

Figure 2. Dynamics of the amount of goods export in terms of the main geographical areas, million USD 
At the same time, in the conditions of foreign trade development, increase of the amount of foreign economic operations and the amount of subjects of foreign economic activity, limited time for inspection of vehicles while crossing the customs border and the time for customs clearance of goods, there is a need to simplify customs procedures while maintaining the proper level of customs security.

In the European Union there are different concepts for regulation the activities of the customs brokers, but in general, their methods can be divided into 2 groups. In the first group we will include the states in which, from the ancient times, the access to the mediation activities is well protected and it is determined that the representative of the customs broker must meet special requirements. To these countries belong Greece, Spain, Italy and Portugal. The second group is characterized by less stringent requirements for customs clearance agents, relations between customs brokers and subjects of foreign economic activity are essentially unregulated. Even without an assessment of the professional competence from the customs authorities, a person has an opportunity to practice this activity [14, p. 195].

If we compare the domestic requirements to the activities of the customs broker with European ones, Ukraine should be included into the first group, since Ukrainian legislation imposes certain requirements for customs broker's activities.

In France, the profession of the customs broker was first mentioned in 1935. French law defines a customs broker as a person holding an appropriate post related to the execution of customs formalities on behalf of a stranger, that is, subjects of foreign economic activity. Ministerial accreditation is provided on the basis of paying capacity and work experience, that is, the demonstration of one's abilities to perform customs operations is necessary. Attention is also paid to respectability, that is, to the absence of violations of tax and criminal law.

The permission to conduct the activity of the customs broker in France is granted. Interrelations with the customs authority are fixed by the agreement, which is also submitted for formal confirmation to the Ministry of Finance. Today, 825 people

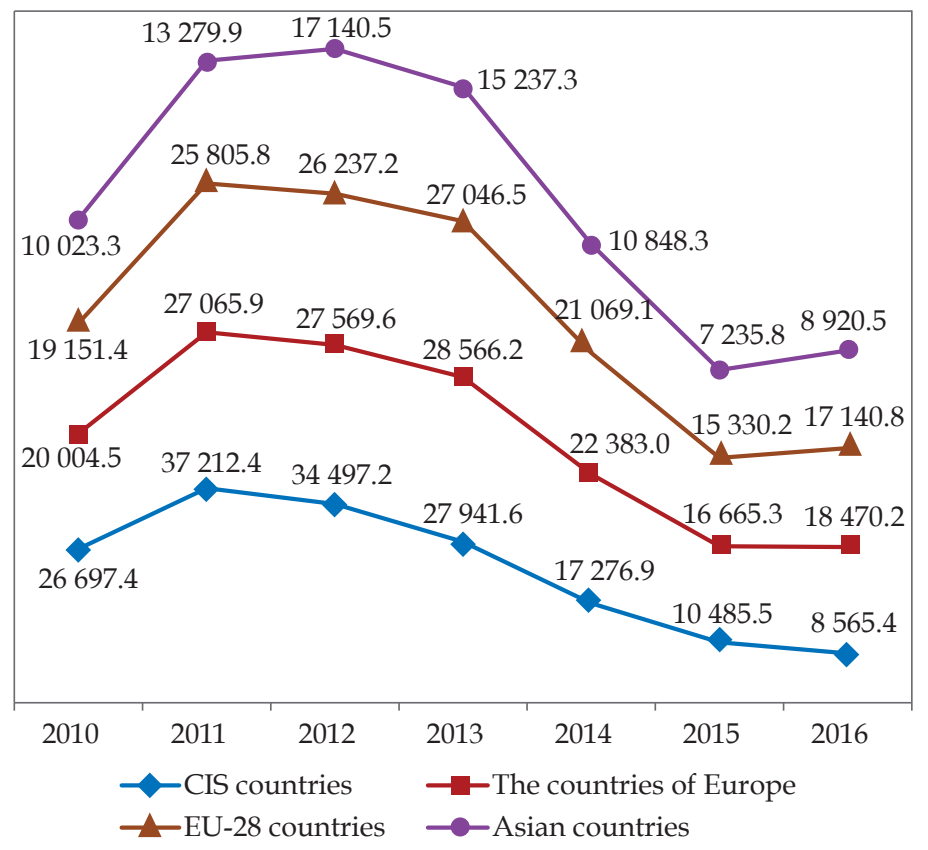

Figure 3. Dynamics of the amount of goods import in terms of the main geographical areas, million USD 
are actively involved in the provision of customs services in France. Annually, on average, 20 new permits are granted.

Ukraine should borrow from France the practice of checking applicants for customs broker activities' implementation for the absence of tax perpetrations. However, the political culture of the French is much higher than of the Ukrainians, and therefore this innovation will cause the resentment on the part of Ukrainian customs brokers.

In the process of monitoring the foreign experience of customs broker activity regulation, the main models of state regulation of such activity were systemized (see Table 2) [15].

\section{Table 2}

State regulation models of customs broker activity

\begin{tabular}{|l|l|l|l|}
\hline Model & $\begin{array}{l}\text { Level of } \\
\text { regulation }\end{array}$ & $\begin{array}{l}\text { Essence of } \\
\text { regulation }\end{array}$ & $\begin{array}{l}\text { Examples } \\
\text { of appli- } \\
\text { cation }\end{array}$ \\
\hline 1 model & $\begin{array}{l}\text { Absence } \\
\text { of state } \\
\text { adminis- } \\
\text { tration }\end{array}$ & $\begin{array}{l}\text { Solving all } \\
\text { issues related } \\
\text { to customs } \\
\text { representation } \\
\text { on the basis } \\
\text { and principles } \\
\text { of self-regu- } \\
\text { lation }\end{array}$ & $\begin{array}{l}\text { Germany } \\
\text { Great } \\
\text { Britain } \\
\text { Northern } \\
\text { Ireland }\end{array}$ \\
\hline 2 model & $\begin{array}{l}\text { Control by } \\
\text { the appro- } \\
\text { priate de- } \\
\text { partment } \\
\text { (customs } \\
\text { authorities } \\
\text { custom } \\
\text { house) }\end{array}$ & $\begin{array}{l}\text { Control at } \\
\text { the level of } \\
\text { Central Body } \\
\text { of executive } \\
\text { power in } \\
\text { the customs } \\
\text { sphere }\end{array}$ & $\begin{array}{l}\text { USA } \\
\text { Canada } \\
\text { France }\end{array}$ \\
\hline 3 model & $\begin{array}{l}\text { Strong au- } \\
\text { thoritative } \\
\text { control } \\
\text { by the } \\
\text { ministry }\end{array}$ & $\begin{array}{l}\text { Strengthening } \\
\text { of administra- } \\
\text { tion, rigid re- } \\
\text { quirements to } \\
\text { customs clear- } \\
\text { ance agents' } \\
\text { activity }\end{array}$ & $\begin{array}{l}\text { Breece } \\
\text { Byelorus- } \\
\text { sia }\end{array}$ \\
$\begin{array}{l}\text { Italy } \\
\text { Spaind }\end{array}$ \\
\hline Spain \\
\hline
\end{tabular}

Along with this, from the foreign experience of regulating the activities of the customs brokers it is worth to draw the following aspects. Firstly, if the customs broker was convicted for violating tax legislation, for corruption, for thefts, then he/ she loses the right to accomplish customs broker activity. Such innovation would stimulate Ukrainian customs brokers to observe legislation more seriously.
Secondly, the function of Greek customs brokers who accomplish the consulting not only customs legislation but also tax legislation, is relevant. For Ukraine, due to the consolidation of the State Customs Service with the State Tax Service, such innovation would be beneficial, would lead to the expansion of the functions of customs brokers and would give impetus to the development of tax consultants.

The importance of the customs broker's professionalism is extremely significant for the whole process totally, therefore, it is necessary to treat responsibly to its choice. In order to avoid possible problems, it is necessary to make sure that the broker enterprise is the part of the state register of customs brokers and has the license for the right to accomplish customs broker activities. When choosing a mediator attention is drawn to his/her personal qualities, presence of his/her connection in business and business circles. It is mandatory to receive information about the customs broker from his/her clients, competitors, as well as from other partners and contractors [16, p. 85].

There may be cases, when the cost price of goods, purchased and imported at a very low price, grows so much on the territory of Ukraine because of the taxes, customs payments, charges and the need of obtaining licensing documents, that further promotion of the product in the market has no practical sense. In order to avoid this, the customs broker in advance calculates the amount of future expenses, taking into account customs payments and other expenses.

The Customs Code, which is currently in force in Ukraine, does not sufficiently provide the mechanisms which would encourage the competition between licensed brokers working on a legal basis. With their deductions, which replenish the treasury, would simultaneously close the road to the customs services market for illegal and semi-legal intermediaries. As a result, the loser is both: the state and brokers: the first loses budgetary incomes, the second - clients who are tempted by low rates of illegal brokers. Therefore, 
both professional brokers and the state are interested in developing a unified regulatory and legal framework, that would contribute to creating the favourable climate in the market of customs services. Another problem that customs brokers face today is mistrustful, and in some cases, negative attitude towards the broker by employees of customs authorities, caused by the lack of confidence in the relatively new participants in the market of customs services.

\section{Conclusions}

Thus, the use of customs broker services in Ukraine is a necessary step towards the further integration of the country into the civilized development of its external economic relations, as well as towards the significant simplification of the interaction between customs authorities and the participants of the external economic relations, towards the reduction of the level of violations and crimes at the customs.

The influence of intermediaries on customs activities and the process of shifting of goods, objects and vehicles has a significant role, which is the fulfillment of functions and tasks, closely related to the tasks of the customs authorities and aimed at ensuring the process of realization of customs formalities through the provision of services of declaration, transportation, storage and related services, necessary for the effective realization, by the subjects of economic activity, of their right to shift objects across the customs border of Ukraine.

Activities of the customs brokers in the procedure of customs clearance of goods are essential. Their professional knowledge helps the subjects of external economic activity to implement appropriate customs procedures in time and therefore to accelerate the external trade turnover of goods.

Thus, one of the main priorities of the State Fiscal Service of Ukraine at present stage is the task of preparing and implementing in the activity of subjects of customs legal relations some modern, adjusted to the European legislation, legal acts designed to protect both the national economic interests of the state and the interests of the customs divisions of SFS of Ukraine and business intermediary structures providing relevant services in the external trade sphere.

\section{References}

1. Friedman T. L. The World is Flat: A Brief History of the Twenty-First Century. New York, Farrar, Straus and Giroux, 2005. 674 p.

2. Arvis J. F., Shepherd B. Global Connectivity and Export Performance. World Bank, Washington, DC, 2013. Available at: https:/ / openknowledge.worldbank.org/handle/10986/17026.

3. Karpova O., Mayburov I. A Comparative Analysis of the Customs Procedures in China and Russia. Proceedings of the 29th International Business Information Management Association Conference (IBIMA). May 3-4, 2017, Vienna (Austria). Vienna, 2017. Pp. 4059-4072. (In Russ.)

4. Goetschalckx M., Vidal C. J., Dogan K. Modeling and Design of Global Logistics Systems: A Review of Integrated Strategic and Tactical Models and Design Algorithms. European Journal of Operational Research, 2002, no. 143, pp. 1-18.

5. Kireenko A. P., Zavyalova E. O. The Impact of Scales and Structure of Foreign Trade on Socio-Economic Development (a Comparative Analysis on the Example of the Subjects of the Siberian Federal District). Izvestiya Irkutskoy gosudarstvennoy ekonomicheskoy akademii = Izvestiya of Irkutsk State Economics Academy, 2014, no. 3, pp. 27-36. (In Russ.)

6. Bondarenko I. O. Services in Customs. Mitna sprava, 2004, no. 6, pp. 46-52. (In Ukrain.)

7. Dunska A. R. Resellers in Foreign Trade: Problems of Definition and Classification. Ekonomichniy visnik NTUU «KPI»: zbirnik naukovih prats, 2012, no. 9, pp. 89-95. (In Ukrain.)

8. Pastor C. B., Nieva J. G., Palomares F. L. T. Customs Brokers: their Vital Role in Mediating Transactions Between Selected Importers in Metro Manila and the Bureau of Customs. Proceedings of the DLSU Research Congress, 2015, no. 3, pp. 1-12.

9. Wieslaw „Wes” Czyżowicz, Ewa Gwardzińska. Customs Representation in Poland. Customs, 2012, no. 1, pp. 8-19.

10. Grainger A. Customs and Trade Facilitation: From Concepts to Implementation. World Customs Journal, 2007, no. 2, 1, OECD.

11. Bondarenko I. O. Mediation in Customs Relations: Existing and Prospective Legislation. Mitna sprava, 2005, no. 2, pp. 49-53. (In Ukrain.) 
12. Svitlak I. I. The Organizational Principles of Mediation Proceedings Customs Broker or Carrier in Ukraine. Irpin, 2006, no. 22. (In Ukrain.)

13. Melnik T. M. Suchasni tendentsiyi ta chinniki rozvitku zovnishnoyi torgivli Ukrayini [Current Trends and Factors of Foreign Trade of Ukraine]. 2011. Available at: http:// www.nbuv.gov.ua. (In Ukrain.)

14. Medvid Yu. O., Korniychuk O. O. Identifying Priority Customs Formalities in the Control of Authenticity of Goods Declaration. Globalni ta natsionalni problemi ekonomiki, 2016, no. 10, pp. 193-196. (In Ukrain.)

15. Gvardzinska E. Customs intermediary services in customs procedures (for example, customs agencies and tax advisers). Visnik Akademiyi mitnoyi sluzhbi Ukrayini. Ser.: Pravo, 2010, no. 2, pp. 170-179. (In Russ.)

16. Korobkova O. M. Forming an effective mechanism for regulating customs brokerage. Ekonomika ta derzhava, 2016, no. 2, pp. 82-86. (In Ukrain.)

\section{Authors}

Evgeny P. Bondarenko - PhD in Economics, Associate Professor of the Department of Taxes and Fiscal Policy, Ternopil National Economic University, Ternopil, Ukraine (11 Lvivska Str. (TNEU Building 1), 46020, Ternopil, Ukraine); ORCID 0000-00016856-4855; e-mail: r0b0ta@ukr.net

Fedor P. Tkachyk - PhD in Economics, Associate Professor of the Department of Taxes and Fiscal Policy, Ternopil National Economic University, Ternopil, Ukraine (11 Lvivska Str. (TNEU Building 1), 46020, Ternopil, Ukraine); ORCID 0000-00024783-6919; e-mail: tkachyk.fp@gmail.com

\section{Информация об авторах}

Бондаренко Евгений Петрович - кандидат экономических наук, доцент кафедры налогов и фискальной политики, Тернопольский национальный экономический университет, г. Тернополь, Украина (46000, Украина, г. Тернополь, ул. Львовская, 11); ORCID 0000-0001-6856-4855; e-mail: r0b0ta@ukr.net

Ткачик Федор Петрович - кандидат экономических наук, доцент кафедры налогов и фискальной политики, Тернопольский национальный экономический университет, г. Тернополь, Украина (46000, Украина, г. Тернополь, ул. Львовская, 11); ORCID 0000-0002-4783-6919; e-mail: tkachyk.fp@gmail.com

\section{For citation}

Bondarenko E. P., Tkachyk F. P. Customs Mediation in Foreign Trade: Scientific and Practical Aspects. Journal of Tax Reform, 2017, vol. 3, no. 3, pp. 170-181. DOI: $\underline{10.15826 / \text { itr.2017.3.3.038 }}$

\section{Апя цитирования}

Бондаренко Е. П. Таможенное посредничество во внешней торговле: научно-практические аспекты / Е. П. Бондаренко, Ф. П. Ткачик // Journal of Tax Reform. - 2017. - T. 3, № 3. - C. 170-181. - DOI: 10.15826/itr.2017.3.3.038

\section{Article info}

Received November 10, 2017; accepted December 3, 2017

\section{Информация о статье}

Дата поступления 10 ноября 2017 г.; дата принятия к печати 3 декабря 2017 г. 